\title{
HUBUNGAN MOTIVASI BELAJAR DENGAN PRESTASI BELAJAR BAHASA ARAB MAHASISWA BIDIKMISI
}

\author{
Weny Listya Jayanti ${ }^{1}$, Ety Nur Inah ${ }^{1}$, Aeni Khairunnisa ${ }^{1}$ \\ ${ }^{1}$ Fakultas Tarbiyah dan Ilmu Keguruan, Institut Agama Islam Negeri Kendari \\ Jl. Sultan Qaimuddin No. 17 Baruga, Kendari, Indonesia \\ Email: ety_nurinah@yahoo.com; Lukmansani@ymail.com
}

\begin{abstract}
Abstrak
Penelitian kuantitatif ini bertujuan untuk mengetahui motivasi belajar, prestasi belajar pada mata kuliah bahasa Arab dan hubungan motivasi belajar dengan prestasi belajar bahasa Arab mahasiswa Bidikmisi di Kendari. Data yang diambil dari sampel $(n=40)$ dikumpul menggunakan observasi, angket, dan dokumentasi lalu dianalisis menggunakan teknik analisis statistik deskriptif dan analisis inferensial. Hasil analisis deskriptif data variabel $X$ menunjukan nilai mean 61,48 dari skor idealnya, dengan frekuensi tertinggi $(24=60 \%)$ pada interval presentase 61-80\%. Hasil ini umumnya menunjukkan motivasi belajar bahasa Arab mahasiswa Bidikmisi pada kategori tinggi. Hasil analisis deskriptif data variabel Y menunjukkan nilai mean $(81,2)$ dari skor idealnya, dengan frekuensi tertinggi $(20=50 \%)$ pada interval presentase 61-80\%. Hasil ini umumnya menunjukkan prestasi belajar bahasa Arab mahasiswa Bidikmisi pada kategori tinggi. Hasil analisis inferensial menunjukkan bahwa tidak terdapat hubungan signifikan antara motivasi belajar dengan prestasi belajar bahasa Arab mahasiswa Bidikmisi $\left(r^{2}=2,5 \%\right)$, sedangkan sisanya 97,5\% dipengaruhi oleh faktor lain yang tidak dibahas dalam penelitian ini.
\end{abstract}

Kata kunci: Belajar Bahasa Arab; mahasiswa Bidikmisi; motivasi belajar; prestasi belajar

\begin{abstract}
This study aims to determine students' motivation and achievement in learning Arabic and the relationship between these two variables among Bidikmisi students at an Islamic higher education in South East Sulawesi. Data collected from the sample $(n=40)$ through observation, questionnaires, and documentation were then analyzed using descriptive and inferential analysis. The results of descriptive analysis of $x$ variable shows the mean value $=61.48$ of the ideal score, with the highest frequency, i.e. $24=60 \%$ in the interval of 61-80\%. This generally shows the participants' motivation in learning Arabic
\end{abstract}


in high category. Meanwhile, the results of descriptive analysis of y variable shows the mean value $=81.2$ from the ideal score, with the highest frequency, i.e. $20=50 \%$ in the interval of $61-80 \%$. It means that the achievement of learning Arabic is in high category as well. The result of inferential analysis refers to no significant relationship result. This study implies that there is no relationship between students' learning motivation and achievement with a ratio of $2.5 \%$, while the remaining $97.5 \%$ is influenced by other factors not discussed in this study.

Keywords: Bidikmisi students; learning achievement; learning Arabic; learning motivation

\section{A. PENDahuluan}

Pendidikan merupakan bagian yang tidak terpisahkan dari kehidupan manusia karena pendidikan merupakan kebutuhan mutlak yang harus dipenuhi sepanjang hidup. Pendidikan adalah proses pengembangan pengetahuan, sikap dan kepribadian secara bertanggung jawab, sehingga manusia memiliki kemampuan mengelola, bertahan hidup serta dapat beradaptasi dengan lingkungannya. Dalam dunia pendidikan, penguasaan bahasa asing menjadi hal penting yang bisa menunjang suatu keberhasilan. Bahasa merupakan salah satu unsur kebudayaan umat manusia yang membedakan suatu kelompok masyarakat dengan kelompok masyarakat lainnya. Bahasa juga merupakan unsur bunyi yang menjadi alat komunikasi manusia satu dengan manusia yang lain dalam menyampaikan ide-idenya. Oleh karena itu, bahasa merupakan suatu kebutuhan yang harus terpenuhi untuk menciptakan komunikasi dalam kehidupan bermasyarakat dan berbangsa (Mulu, 2011).

Bahasa Arab sebagai salah satu bahasa resmi dunia internasional memiliki keistimewaan di antara bahasa lain di dunia karena bahasa Arab merupakan bahasa agama, yakni bahasa yang digunakan oleh Alquran dan hadis sebagai sumber ajaran Islam. Dalam rangka menjadikan perguruan tinggi keagamaan Islam (PTKI) sebagai pusat pengembangan mahasiswa yang memiliki keunggulan akademik dan moral maka perlu adanya reformulasi ilmu pengetahuan integratif. Dalam mewujudkan hal ini, PTKI memiliki riwayat berbeda dengan perguruan tinggi umum, dimana perguruan tinggi Islam didirikan untuk memenuhi kebutuhan akademik, agama, ideologi, dan politik. Oleh karena itu, untuk lebih mengartikulasikan perannya, PTKI berusaha mengembangkan konsep keilmuan dan moralitas. Untuk mencapai hal tersebut maka diperlukan strategi pengembangan kelembagaan di bawah Direktorat Pendidikan Tinggi Islam (DIKTIS) yang mampu mewadahi sistem pendidikan tinggi dan pesantren. Berdasarkan filosofi ini, DIKTIS memandang bahwa pendirian Ma'had Al-Jami'ah di PTKI sangat penting untuk merealisasikan 
program integral yang sistematis sejalan dengan Sistem Pendidikan Nasional dan visi-misi Kementerian Agama Republik Indonesia.

Ma'had Al-Jami'ah yang terletak di kampus IAIN Kendari merupakan wahana pembinaan mahasiswa dalam bidang pengembangan ilmu keagamaan dan kebahasaan. Beberapa kegiatan di Ma'had Al-Jami'ah berbasis bahasa, seperti kegiatan pidato dua bahasa, dan kegiatan pembelajaran bahasa Arab dan Inggris khususnya untuk mahasiswa Bidikmisi. Kegiatan pidato dilakukan satu kali seminggu, tepatnya malam Sabtu. Dalam kegiatan ini, mahasiswa dilatih untuk bisa tampil menggunakan bahasa asing dengan fokus penilaian pada susunan bahasa, isi pidato, dan keberanian. Selain itu, kegiatan pembelajaran bahasa Arab di Ma'had Al-Jami'ah dilakukan seminggu sekali, mencakup 16 kali pertemuan per semester. Kegiatan ini diajar oleh pembina Bidikmisi menggunakan buku bahasa Arab, yaitu Nahwu, Sorf, dan Tamrin Lughoh. Kriteria penilaian pembelajaran bahasa Arab diambil dari kehadiran, tugas harian, ujian tengah semester dan ujian akhir semester. Kedua kegiatan tersebut diikuti oleh mahasiswa Bidikmisi tahun akademik 2016/2017 $(\mathrm{n}=40)$. Penerapan pembelajaran bahasa Arab ini baru diaktifkan kembali di tahun akademik 2015/2016. Sebelumnya, di tahun 2014/2015, pernah diterapkan namun kurang efektif karena beberapa hal. Dari hasil observasi awal, peneliti menilai motivasi belajar bahasa Arab mahasiswa Bidikmisi tahun akademik 2016/2017 ini dianggap kurang karena sarana dan prasarana yang ada di Ma'had Al-Jami'ah IAIN Kendari masih kurang lengkap sehingga berpengaruh terhadap motivasi belajar mereka.

Dornyei (2001) menegaskan bahwa motivasi adalah salah satu faktor yang mempengaruhi kualitas pendidikan. Motivasi yang baik dalam suatu pembelajaran akan mempengaruhi prestasi belajar mahasiswa. Prestasi belajar adalah hasil yang dicapai oleh mahasiswa dari proses belajar yang dilakukan selama beberapa waktu yang berupa pengetahuan, nilai-nilai dan keterampilan yang dibuktikan melalui tes hasil belajar. Untuk mengetahui prestasi belajar mahasiswa, dapat dilakukan dengan melihat hasil-hasil tes belajar yang telah dilakukan baik berupa angka-angka maupun perubahan-perubahan positif dari dalam diri mahasiswa, apakah hasilnya meningkat, menetap atau bahkan menurun. Berdasarkan pernyataan di atas, penulis hendak meneliti hubungan motivasi belajar dengan prestasi belajar bahasa Arab mahasiswa Bidikmisi, khususnya pada tahun ajaran 2016/2017.

Menurut McDonald (dalam Sardiman, 1988) motivasi adalah perubahan energi dalam diri seseorang yang ditandai dengan munculnya "feeling" dan didahului dengan tanggapan terhadap adanya tujuan. Huitt (2011) mengatakan bahwa motivasi adalah suatu kondisi atau status internal (kadang-kadang diartikan sebagai suatu kebutuhan, keinginan atau hasrat) yang mengarahkan perilaku seseorang untuk aktif bertindak dalam rangka mencapai suatu tujuan. Jadi, ada tiga kata kunci tentang pengertian motivasi menurut Huitt (2011), 
yaitu: a) kondisi atau status yang mengaktifkan dan memberi arah pada perilaku seseorang; b) keinginan yang memberi tenaga dan mengarahkan perilaku seseorang untuk mencapai suatu tujuan; dan, c) tingkat kebutuhan dan keinginan akan berpengaruh terhadap intensitas perilaku seseorang. Di dalam proses belajar, motivasi sangat diperlukan sebab seseorang yang tidak mempunyai motivasi dalam belajar tidak akan melakukan aktivitas belajar (Dornyei, 2001). Hal ini merupakan tanda bahwa sesuatu yang dikerjakan tersebut tidak sesuai dengan kebutuhannya.

Motivasi belajar lebih mengutamakan respon kognitif, yaitu kecenderungan siswa untuk mencapai aktivitas akademik yang bermakna dan bermanfaat serta mencoba untuk mendapatkan keuntungan dari aktifitas tersebut. Hal ini didukung oleh Syah (2002) yang mengatakan bahwa motivasi intristik adalah motivasi yang berasal dari dalam diri pribadi siswa sendiri yang dapat mendorong terjadinya tindakan belajar. Siswa yang memiliki motivasi belajar akan memperhatikan pelajaran yang disampaikan, membaca materi sehingga bisa memahaminya, dan menggunakan strategi-strategi tertentu yang mendukung.

Di dalam motivasi belajar terdapat jenis-jenis motivasi seperti motivasi intrinsik (motivasi dari dalam diri pribadi) dan motivasi ekstrinsik (motivasi dari luar diri pribadi). Motivasi intrinsik adalah hal dan keteladanan yang berasal dari dalam diri pribadi siswa yang dapat mendorong melakukan tindakan belajar (Syah, 2002). Jadi, motivasi intrinsik muncul berdasarkan kesadaran dengan tujuan tertentu, bukan sekedar atribut dan seremonial. Motivasi intrinsik yang dimaksud seperti mempelajari buku-buku yang berhubungan dengan pelajaran, belajar secara mandiri, sungguh-sungguh dalam mengerjakan tugas, disiplin dalam belajar, perhatian terhadap pelajaran, senang berdiskusi mengenai pelajaran, serta memiliki keinginan untuk berprestasi.

Faktor-faktor yang dapat menimbulkan motivasi intrinsik adalah sebagai berikut: 1) adanya kebutuhan; 2) adanya pengetahuan tentang kemajuan diri sendiri; dan, 3) adanya cita-cita atau inspirasi. Menurut Sabri (2001) motivasi intrinsik adalah motif-motif yang menjadi aktif atau berfungsi yang tidak memerlukan rangsangan dari luar karena dalam diri setiap individu sudah ada dorongan untuk melakukan sesuatu. Bila seseorang telah memiliki motivasi intrinsik dalam dirinya, maka ia secara sadar akan melakukan suatu kegiatan yang tidak memerlukan motivasi dari luar. Dalam aktifitas belajar, motivasi intrinsik sangat diperlukan, terutama dalam belajar sendiri. Seseorang yang tidak memiliki motivasi intrnisik sulit sekali melakukan aktivitas belajar secara terus menerus.

Sementara itu, motivasi ekstrinsik adalah hal atau keadaan yang datang dari luar individu siswa yang mendorongnya melakukan kegiatan belajar. Bentuk motivasi ekstrinsik ini merupakan suatu dorongan yang tidak secara 
mutlak berkaitan dengan aktivitas belajar. Siswa tersebut rajin belajar untuk memperoleh hadiah yang telah dijanjikan orang tuanya, pujian dari gurunya dan lain sebagainya. Peraturan atau tata tertib sekolah, suri tauladan orang tua, guru dan lain-lain merupakan contoh kongkrit dari motivasi ekstrinsik yang dapat mendorong siswa untuk belajar. Dalam prespektif kognitif, motivasi intrinsik lebih signifikan bagi siswa karena lebih murni dan langgeng serta tidak bergantung pada dorongan atau pengaruh orang lain. Hal ini tidak berarti bahwa motivasi ekstrinsik tidak baik dan tidak penting. Dalam kegiatan belajar mengajar, motivasi ekstrinsik tetap penting karena kemungkinan besar keadaan siswa dinamis berubah-ubah dan juga mungkin komponen-komponen lain dalam proses belajar mengajar ada yang kurang menarik baginya sehingga mereka tidak bersemangat dalam melakukan proses belajar mengajar baik di sekolah maupun di rumah. Mengingat setiap siswa tidak sama tingkat motivasi belajarnya maka motivasi intrinsik sangat diperlukan.

Dalam kegiatan belajar mengajar, peranan motivasi baik intrinsik maupun ekstrinsik sangat diperlukan. Dengan motivasi, siswa dapat mengembangkan aktivitas dan inisiatif sehingga lebih terarah dan mampu memelihara kerukunan dalam melakukan kegiatan belajar. Motivasi sangat berperan dalam kegiatan belajar. Siswa yang dalam proses belajarnya memiliki motivasi yang kuat dan jelas cenderung lebih tekun dan berhasil dalam belajar. Makin tepat motivasi yang diberikan, makin berhasil pelajaran tersebut sehingga motivasi senantiasa akan menentukan intensitas belajar siswa. Adapun fungsi motivasi menurut Sardiman (1988), yaitu a) mendorong manusia untuk berbuat, menjadi penggerak atau motor yang melepas energi; b) menentukan arah perbuatan menuju tujuan yang akan dicapai; dan, menyeleksi perbuatan yaitu dengan menentukan perbuatan apa yang akan dilakukan guna mencapai tujuan dengan menghindari perbuatan yang tidak bermanfaat.

Sehubungan dengan hal tersebut maka fungsi motivasi terbagi menjadi tiga. Pertama, motivasi mendorong manusia untuk berbuat sebagai penggerak atau motor untuk melepaskan energi. Motivasi ini sebagai penggerak dalam mengerjakan sesuatu. Kedua, motivasi menentukan arah perbuatan ke arah yang akan dicapai. Dengan demikian motivasi dapat memberi arah kegiatan yang harus dikerjakan sesuai dengan rumusan tujuan. Ketiga, motivasi membantu manusia menyeleksi perbuatan dengan cara menentukan perbuatanperbuatan apa yang harus dikerjakan sesuai dengan tujuan. Disamping itu, ada juga fungsi-fungsi lain yaitu sebagai pendorong usaha dan pencapai prestasi. Adanya motivasi yang baik dalam belajar akan menunjukkan hasil yang baik. Dengan kata lain, adanya usaha yang tekun dan disadari adanya motivasi maka seseorang yang belajar akan melahirkan prestasi yang baik (Sardiman, 1998).

Ada beberapa hal yang mempengaruhi motivasi belajar. Yusuf (dikutip dari Suaibah, 2012) menyatakan terdapat dua faktor yang mempengaruhi 
motivasi belajar, yaitu faktor internal dan faktor eksternal. Faktor internal terkait dengan hal yang berasal dari dalam diri siswa, sedangkan faktor eksternal berasal dari lingkungan di luar diri siswa. Faktor internal atau faktor yang berasal dari diri siswa meliputi faktor fisik dan psikologis. Faktor fisik yang dimaksud meliputi nutrisi atau gizi, kesehatan, dan fungsi-fungsi fisik (terutama panca indera). Jika siswa kurang gizi, ia akan rentan terhadap penyakit yang mengakibatkan penurunan kemampuan belajar, berfikir, dan konsenterasi. Terkait faktor psikologis, hal ini berhubungan dengan aspekaspek yang mendorong atau menghambat aktifitas belajar pada siswa. Faktor yang mendorong aktifitas belajar menurut Frandsen (dikutip dari Suaibah, 2012) adalah: a) rasa ingin tahu dan ingin menyelidiki dunia (lingkungan) yang lebih luas; b) sifat kreatif dan keinginan untuk selalu maju; c) keinginan untuk mendapat simpati dari orang tua, guru, dan teman-teman; d) keinginan untuk mendapat rasa aman apabila menguasai pelajaran; dan, e) adanya ganjaran atau hukuman sebagai akhir dari proses belajar. Terkait faktor psikis, yang menghambat adalah: a) tingkat kecerdasan yang lemah; b) gangguan emosional, seperti merasa tidak aman, tercekam rasa takut, cemas, dan gelisah; c) sikap dan kebiasaan belajar yang buruk, seperti tidak menyukai mata pelajaran tertentu, malas belajar, tidak memiliki waktu belajar yang teratur, dan kurang terbiasa membaca buku mata pelajaran. Kedua faktor yang dipaparkan tersebut merupakan faktor dari dalam diri siswa yang dapat mempengaruhi motivasi belajar.

Sementara itu, faktor eksternal atau faktor yang berasal dari lingkungan meliputi faktor non-sosial dan faktor sosial. Yang dimaksud dengan faktor non-sosial adalah keadaan cuaca (panas atau dingin), waktu (pagi, siang, malam), tempat (sepi, bising, atau kualitas sekolah tempat belajar), sarana dan prasarana atau fasilitas belajar. Faktor eksternal lainnya adalah faktor sosial yang meliputi faktor manusia (guru, konselor, dan orang tua), baik yang hadir secara langsung maupun tidak langsung (foto atau suara). Terkait faktor ini, Nasution (2002) menegaskan bahwa proses belajar akan berlangsung dengan baik apabila guru mengajar dengan cara yang menyenangkan, seperti bersikap ramah, memberi perhatian pada semua siswa, serta selalu membantu siswa yang mengalami kesulitan belajar.

Dalam konteks penelitian ini, yaitu pembelajaran bahasa Arab, yang dimaksud motivasi belajar bahasa Arab adalah motivasi yang mendorong dan memberi semangat siswa dalam mempelajari bahasa Arab. Dalam mempelajari bahasa Arab diperlukan dorongan atau motivasi di diri siswa. Oleh karena itu, siswa sedikit banyaknya harus mengetahui tentang pentingnya belajar bahasa Arab (Mulu, 2011). Motivasi belajar bahasa Arab erat kaitannya dengan motivasi religi. Imam Syafi'i berkata bahwa wajib atas tiap-tiap muslim untuk belajar bahasa Arab jika ingin sampai kepada kesungguhan dalam melaksanakan kefarduannya. Jika bukan karena mengamalkan hal fardu maka 
belajar bahasa Arab hukumnya sunah bagi selain yang ingin mengetahui seluk beluk syariat Islam, karena wajib bagi para alim syariat belajar bahasa Arab untuk memahami tentang syariat Alquran atau syariat hadis. Tidak ada alasan lain untuk tidak mempelajari bahasa Arab bagi seluruh muslim karena mempelajari bahasa Arab wajib hukumnya guna memahami Alquran dan hadis sebagi pedoman hidup. Dalam konteks penelitian ini, peneliti hendak melihat motivasi mahasiswa Bidikmisi yang ada di Ma'had Al-Jami'ah IAIN Kendari terkait semangat belajar bahasa Arab yang tergambar pada prestasi belajar mereka.

Syah (2009) menyatakan prestasi belajar siswa adalah gambaran kemampuan siswa yang diperoleh dari hasil penilaian proses belajar siswa dalam mencapai tujuan pengajaran. Dalam kamus bahasa Indonesia (1999, h.788) prestasi belajar dinyatakan sebagai "hasil yang telah dicapai atau dikerjakan". Berdasarkan pengertian di atas maka yang dimaksud dengan prestasi belajar adalah hasil belajar/ nilai pelajaran sekolah yang dicapai oleh siswa berdasarkan kemampuannya/usahanya dalam belajar. Dalam hal ini, prestasi belajar merupakan suatu kemajuan dalam perkembangan siswa setelah ia mengikuti perkembangan belajar dalam waktu tertentu. Seluruh pengetahuan, keterampilan, kecakapan, dan perilaku individu terbentuk dan berkembang melalui proses belajar.

Perkembangan belajar yang dijalani siswa dipengaruhi oleh dua faktor utama, yaitu faktor lingkungan dan faktor yang datang dari siswa (Clark, dalam Hadisi, 2009). Clark menegaskan bahwa $70 \%$ prestasi belajar di sekolah dipengaruhi oleh kemampuan siswa, sedangkan 30\% dipengaruhi oleh faktor lingkungan. Disamping faktor kemampuan yang dimiliki siswa, ada faktor lain seperti motivasi belajar, minat dan perhatian, sikap dan kebiasaan belajar, ketekunan, sosial, ekonomi dan faktor fisik dan psikis. Oleh sebab itu, hasil belajar siswa di sekolah dipengaruhi oleh kemampuan siswa dan kualitas pengajaran. Pendapat ini sesuai dengan teori belajar Bloom (dalam Hadisi, 2009) yang membagi tiga variabel utama dalam teori belajar di sekolah, yakni karakteristik individu, kualitas pengajaran, dan hasil belajar siswa. Sedangkan menurut Caroll (dalam Kardon, 2012), hasil belajar siswa dipengaruhi oleh lima faktor, yakni (a) bakat belajar, (b) waktu yang tersedia untuk belajar, (c) waktu yang diperlukan siswa untuk menjelaskan pelajaran, (d) kualitas pengajaran, dan (e) kemampuan individu.

Sehubungan dengan fokus penelitian ini, bahasa Arab yang dimaksud adalah alat yang berbentuk huruf hijaiah yang digunakan oleh orang Arab dalam berkomunikasi dan berinteraksi sosial baik secara lisan maupun tulisan. Menurut Syaikh al-Ghulayayniy, bahasa Arab adalah kalimat yang digunakan bangsa Arab dalam mengutarakan maksud/tujuan mereka. Adapun Ahmad alHasyimiy mengemukakan bahwa bahasa Arab sebagai bunyi yang mengandung sebagian huruf hijaiah (Tim Konsorsium 3 PTAI). Dari definisi 
yang dikemukakan oleh dua orang pakar tersebut, penulis menarik kesimpulan bahwa bahasa Arab adalah alat yang berbentuk huruf hijaiah yang digunakan oleh orang Arab dalam berkomunikasi dan berinteraksi sosial baik secara lisan maupun tulisan.

\section{B. METODE PENELITIAN}

Penelitian ini adalah penelitian kuantitatif karena di dalamnya ada proses menemukan pengetahuan dengan menggunakan data yang berupa angka sebagai alat menemukan keterangan mengenai apa yang ingin diketahui (Nasution, 2002). Penelitian ini mengumpulkan data-data atau informasi obyektif di lapangan mengenai hubungan motivasi dengan prestasi belajar bahasa Arab mahasiswa Bidikmisi di Ma'had Al-Jami'ah IAIN Kendari. Penelitian yang dilaksanakan pada bulan Juni sampai dengan September 2017 mengambil sampel seluruh mahasiswa Bidikmisi yang terdaftar pada tahun akademik 2016/2017 ( $n=40)$ dari seluruh fakultas yang ada di IAIN Kendari. Menurut Arikunto (2006), terkait penentuan sampel, jika populasi kurang dari 100 orang maka diambil seluruhnya. Data yang dikumpulkan dalam penelitian ini melalui angket. Hasil pengumpulan angket dianalisis menggunakan analisis statistik inferensial. Hal ini dilakukan mengingat penelitian ini bersifat kolerasional karena hendak melihat adanya hubungan antara variabel bebas (X) dan variabel terikat $(\mathrm{Y})$ dalam hal ini hubungan motivasi dengan prestasi belajar bahasa Arab mahasiswa Bidikmisi di Ma'had Al-Jami'ah IAIN Kendari.

\section{HASIL DAN PEMBAHASAN}

Pokok masalah yang dikaji dalam penelitian ini adalah hubungan motivasi dengan prestasi belajar bahasa Arab mahasiswa Bidikmisi di Ma'had Al-Jami'ah IAIN Kendari. Telah banyak penelitian motivasi dan prestasi belajar yang dilakukan oleh peneliti sebelumnya pada beberapa variabel dan objek yang berbeda. Penelitian tersebut kemudian dijadikan salah satu bahan rujukan guna melihat hasil dan posisi penelitian sebelumnya dengan hasil penelitian penulis.

Hasil yang diperoleh dalam penelitian ini adalah motivasi belajar mahasiswa merupakan keseluruhan daya penggerak yang ada dalam diri mereka yang menimbulkan kegiatan belajar dan memberi arah kegiatan belajar untuk mencapai tujuan yang dikehendaki oleh mahasiswa yang bersangkutan sebagai subyek belajar.

\section{Motivasi Belajar Bahasa Arab Mahasiswa Bidikmisi}

Terkait motivasi belajar, hasil analisis data yang dikumpulkan dalam penelitian ini akan dideskripsikan dalam bagian ini. Angket motivasi belajar bahasa Arab mahasiswa Bidikmisi di Ma'had Al-Jami'ah IAIN Kendari terdiri 
atas 20 butir pertanyaan yang diberikan kepada 40 responden. Hasil tabulasi dapat dilihat pada Tabel 1 di bawah ini.

Tabel 1. Hasil analisis data variabel X (motivasi belajar)

\begin{tabular}{cc}
\hline Statistik & Variabel X \\
\hline Skor total & 2459 \\
Skor tertinggi & 74 \\
Skor terendah & 40 \\
Rata-rata & 61,48 \\
Standar deviasi (SD) & 8,00 \\
Modus (Mo) & 56 \\
\hline
\end{tabular}

Berdasarkan Tabel 1 di atas, perolehan angket motivasi belajar di Ma'had Al-Jami'ah IAIN Kendari menunjukkan skor total sebesar 2459. Skor tertinggi dari perolehan angket motivasi belajar $(=74)$, skor terendah $(=40)$, rata-rata $(=61,48)$, standar deviasi $(=8,00)$, dan modus $(=56)$. Selanjutnya, untuk mengetahui tingkat motivasi belajar di Ma'had Al-Jami'ah IAIN Kendari, dapat dilihat pada kategorisasi yang ditunjukkan di dalam Tabel 2 berikut ini.

Tabel 2. Kategorisasi perolehan angket motivasi belajar

\begin{tabular}{cccc}
\hline Skor & Frekuensi & Persentase & Kategori \\
\hline $81-100 \%$ & 14 & $35 \%$ & Sangat tinggi \\
$61-80 \%$ & 24 & $60 \%$ & Tinggi \\
$41-60 \%$ & 2 & $5 \%$ & Sedang \\
$21-40 \%$ & - & - & Rendah \\
$0-20 \%$ & - & - & Sangat rendah \\
\hline Jumlah & 40 & $100 \%$ & \\
\hline
\end{tabular}

Berdasarkan hasil kategorisasi pada Tabel 2 di atas, 14 responden berada pada kategori sangat tinggi, 24 responden berada pada kategori tinggi dan 2 responden berada pada kategori sedang. Dengan demikian dapat disimpulkan bahwa motivasi belajar di Ma'had Al-Jami'ah IAIN Kendari berada pada kategori tinggi dengan persentase $60 \%$.

Berdasarkan hasil analisis angket motivasi belajar bahasa Arab mahasiswa Bidikmisi di Ma'had Al-Jami'ah IAIN Kendari, hasilnya dikategorikan tinggi yang diukur berdasarkan jawaban mahasiswa di Ma'had Al-Jami' ah IAIN Kendari dengan jumlah keseluruhan nilai $\left(\sum=2459\right)$ dengan rata-rata sebesar 61,48 . Selanjutnya, dari hasil uji normalitas data motivasi belajar bahasa Arab mahasiswa di Ma'had Al-Jami'ah IAIN Kendari, diperoleh nilai kemiringan kurva sebesar 0,685 yang menunjukan bahwa data dari variabel tersebut berdistribusi normal. Hal ini sejalan dengan penelitian yang dilakukan oleh Suaibah (2012) yang menyimpulkan bahwa motivasi 
berprestasi mahasiswa jurusan Tarbiyah berada pada kategori baik $(82,5 \%)$. Hasil penelitian ini didukung oleh Huitt (2011) yang menyatakan bahwa motivasi merupakan suatu kondisi atau status internal (kadang-kadang diartikan sebagai suatu kebutuhan, keinginan atau hasrat) yang mengarahkan perilaku seseorang untuk aktif bertindak dalam rangka mencapai suatu tujuan. Ada tiga kata kunci terkait motivasi menurut Huitt (2011), yaitu: a) kondisi atau status itu mengaktifkan dan memberi arah pada perilaku seseorang, b) keinginan yang memberi tenaga dan mengarahkan perilaku seseorang untuk mencapai suatu tujuan, dan c) tingkat kebutuhan dan keinginan akan berpengaruh terhadap intensitas perilaku seseorang. Didalam proses belajar, motivasi sangat diperlukan sebab seseorang yang tidak mempunyai motivasi dalam belajar tidak akan mungkin melakukan aktivitas belajar.

\section{Prestasi Belajar Bahasa Arab Mahasiswa Bidikmisi}

Pendidikan dikatakan berhasil jika prestasi belajar yang dicapai mahasiswa sesuai dengan standar yang ditetapkan lembaga pendidikan tersebut sebab jika mahasiswa mencapai prestasi yang baik, berarti keberhasilan pembelajaran telah tercapai. Prestasi belajar bahasa Arab mahasiswa Bidikmisi di Ma'had Al-Jami'ah IAIN Kendari dalam penelitian ini diukur dari nilai ujian akhir mereka yang dipaparkan pada Tabel 3 berikut ini.

Tabel 3. Hasil analisis data variabel Y

\begin{tabular}{cc}
\hline Statistik & Variabel Y \\
\hline Skor total & 3248 \\
Skor tertinggi & 94 \\
Skor terendah & 53 \\
Rata-rata & 81,2 \\
Standar deviasi (SD) & 6,75 \\
Modus (Mo) & 80 \\
\hline
\end{tabular}

Berdasarkan tabel hasil analisis data prestasi belajar bahasa Arab mahasiswa Bidikmisi di atas, diperoleh skor total sebesar 3248 dengan skor tertinggi prestasi belajar bahasa Arab mahasiswa Bidikmisi $(=94)$, skor terendah $(=53)$, rata-rata $(=81,2)$, modus $(=80)$, dan standar deviasi $(=6,75)$. Prestasi belajar bahasa Arab mahasiswa Bidikmisi di Ma'had Al-Jami'ah IAIN Kendari dapat disimpulkan berdasarkan kategorisasi pada Tabel 4.

Berdasarkan hasil kategorisasi prestasi belajar bahasa Arab mahasiswa Bidikmisi di atas, 19 responden berada pada kategori sangat tinggi, 20 responden berada pada kategori tinggi, dan 1 responden pada kategori sedang. Dengan demikian, dapat disimpulkan bahwa prestasi belajar bahasa Arab mahasiswa Bidikmisi berada pada ketegori tinggi dengan persentase $50 \%$. 
Tabel 4. Kategorisasi prestasi belajar (Y)

\begin{tabular}{cccc}
\hline Skor & Frekuensi & Persentase & Kategori \\
\hline $81-100$ & 19 & $47,5 \%$ & Sangat tinggi \\
$61-80$ & 20 & $50 \%$ & Tinggi \\
$41-60$ & 1 & 2,5 & Sedang \\
$21-40$ & - & - & Rendah \\
$0-20$ & - & - & Sangat rendah \\
\hline Jumlah & 40 & $100 \%$ & \\
\hline
\end{tabular}

Prestasi belajar bahasa Arab mahasiswa Bidikmisi di Ma'had Al-Jami'ah IAIN Kendari diukur dari nilai hasil ujian akhir tahun ajaran 2016/2017. Berdasarkan nilai hasil ujian akhir, jumlah keseluruhan nilai $\left(\sum=3248\right)$ dengan nilai rata-rata sebesar 81,2. Selanjutnya, hasil uji normalitas data prestasi belajar bahasa Arab mereka diperoleh nilai kemiringan kurva sebesar 0,178 yang menunjukan bahwa data dari variabel tersebut terdistribusi normal. Hal ini sejalan dengan hasil penelitian yang dilakukan oleh Sultan yang menyimpulkan bahwa pengaruh keaktifan berorganisasi terhadap prestasi belajar sebesar 19,29\%, dan 80,71\% disebabkan oleh faktor lain yang tidak diteliti dalam penelitian.

Kemudian, berdasarkan hasil perhitungan uji t diperoleh thitung 3,91 $\geq$ ttabel 2,00. Hasil ini menunjukkan bahwa koefisien kolerasi antara keaktifan berorganisasi terhadap prestasi belajar mahasiswa belajar mahasiswa sebesar 3,91 adalah signifikan. Setelah melihat nilai dari rhitung dan $r_{\text {tabel }}(=0,244)$ dapat disimpulkan bahwa terdapat pengaruh positif antara keaktifan berorganisasi terhadap prestasi belajar mahasiswa yang didukung oleh penelitian sebelumnya yang menemukan bahwa prestasi belajar siswa adalah gambaran kemampuan mereka yang diperoleh dari hasil penilaian proses belajar siswa dalam mencapai tujuan pembelajaran.

\section{Hubungan Motivasi Belajar dan Prestasi Belajar Bahasa Arab Mahasiswa Bidikmisi}

Uji persyaratan analisis yang digunakan untuk mengetahui normal dan tidaknya sebuah data dalam penelitian ini menggunakan rumus kemiringan kurva. Hasil pengujian normalitas data dengan menggunakan rumus kemiringan kurva menunjukkan bahwa data variabel $\mathrm{X}$ (motivasi belajar) berdistribusi normal. Hal ini dilihat pada nilai hitung $\mathrm{Km}$ yang terdapat diantara -1 dan +1 . Perhitungan data variabel yaitu $-1<\mathrm{Km}=0,685<+1$.

Pengujian ini diperlukan untuk mengetahui hubungan antara kedua variabel yaitu motivasi belajar dengan prestasi belajar bahasa Arab mahasiswa Bidikmisi di Ma'had Al-Jami'ah IAIN Kendari. Berdasarkan hasil perhitungan diinterprestasikan pada $r_{\text {tabel }}$ pada taraf $\alpha=5 \%$ dimana $\mathrm{df}=\mathrm{n}-2$ yakni: $\mathrm{df}=40$ 
- $2=38$, diperoleh nilai $\mathrm{r}_{\text {tabel }}=0,320$. Hal ini berarti $\mathrm{r}_{\text {hitung }} \leq \mathrm{r}_{\text {tabel }}$ atau $\mathrm{r}_{\text {hitung }}=$ $0,16 \leq \mathrm{r}_{\text {tabel }}=0,320$ maka dapat dikatakan bahwa tidak terdapat hubungan antara kedua variabel penelitian ini. Hasil perhitungan menunjukkan bahwa besarnya sumbangan variabel X (motivasi belajar) dengan variabel Y (prestasi belajar bahasa Arab) di Ma'had Al-Jami'ah IAIN Kendari adalah 2,5\% dan sisanya $97,5 \%$ dipengaruhi oleh faktor lain yang tidak dibahas dalam penelitian ini.

Selanjutnya, untuk menguji signifikansi hubungan antara kedua variabel digunakan uji t. Dari perhitungan tersebut, dapat disimpulkan bahwa $\mathrm{df}=40-$ $2=38$. Diperoleh $\mathrm{t}_{\text {tabel }}$ pada taraf signifikan $5 \%=1,685$. Ternyata $\mathrm{t}_{\text {hitung }} \leq \mathrm{t}_{\text {tabel }}$ dimana $\mathrm{t}_{\text {hitung }}=1 \leq \mathrm{t}_{\text {tabel }}=1,685$ maka $\mathrm{H}_{1}$ ditolak dan $\mathrm{H}_{0}$ diterima. Oleh karena itu, dapat disimpulkan bahwa tidak terdapat hubungan signifikan antara motivasi belajar dengan prestasi belajar bahasa Arab mahasiswa Bidikmisi di Ma'had Al-Jami'ah IAIN Kendari.

Berdasarkan hasil perhitungan yang dilakukan oleh peneliti untuk koefisien korelasi atau keterkaitan ditemukan $\mathrm{r}_{\text {hitung }}=0,16 \leq \mathrm{r}_{\text {tabel }}=0,320$. Hal ini menunjukkan adanya korelasi yang sangat rendah sehingga korelasi tersebut diabaikan (dianggap tidak ada korelasi antara variabel $\mathrm{X}$ dan $\mathrm{Y}$ ). Selanjutnya, analisis korelasi dapat dilanjutkan dengan menggunakan rumus koefisien determinasi untuk mengetahui seberapa besar sumbangan variabel motivasi belajar tehadap prestasi belajar bahasa Arab mahasiswa Bidikmisi. Hasil yang diperoleh adalah sebesar 2,5\% dan sisanya 97,5\% yang dipengaruhi oleh faktor lain yang tidak dibahas dalam penelitian ini. Pengujian hipotesis yang digunakan uji t. Berdasarkan hasil perhitungan $t_{\text {hitung }}=1$ ketentuannya apabila $\mathrm{t}_{\text {hitung }} \geq \mathrm{t}_{\text {tabel }}$ maka signifikan, dan apabila $\mathrm{t}_{\text {hitung }} \leq \mathrm{t}_{\text {tabel }}$ maka tidak signifikan. Dari hasil perhitungan diketahui $\mathrm{t}_{\text {hitung }}=1 \leq \mathrm{t}_{\text {tabel }}=1,685 \mathrm{maka}_{1}$ ditolak dan $\mathrm{H}_{0}$ diterima. Jadi, dapat disimpulkan bahwa motivasi belajar dengan prestasi belajar bahasa Arab mahasiswa Bidikmisi tidak signifikan.

Hasil penelitian ini menunjukkan bahwa prestasi belajar tiap mahasiswa berbeda-beda. Kendatipun materi yang diajarkan sama, pengajar sama dan strategi yang diterapkan juga sama, namun belum tentu menghasilkan prestasi belajar yang sama. Syah (2009) mengungkapkan bahwa prestasi belajar dipengaruhi oleh beberapa faktor internal maupun eksternal. Faktor internal terdiri atas kecerdasan/intelegensi, perhatian, bakat, minat, motivasi, kematangan, dan kesiapan. Sedangkan faktor eksternal terdiri atas lingkungan keluarga, lingkungan sekolah, dan lingkungan masyarakat. Menurut Purwanto (2004), faktor yang mempengaruhi prestasi belajar dapat berupa: 1) faktor belajar yang berasal dari luar diri si pelajar yaitu lingkungan, dan instrumental (kurikulum, program, sarana dan guru); 2) faktor yang berasal dari dalam diri si pelajar berupa kondisi fisik secara umum, kondisi panca indera dan faktor psikologis (minat, kecerdasan, bakat, motivasi dan kemampuan kognitif). 
Dari pemaparan di atas dapat ditarik kesimpulan bahwa motivasi belajar bukanlah syarat utama untuk mencapai prestasi belajar. Purwanto (2004) mendudukkan motivasi belajar pada urutan keempat. Dalam penelitian ini, kemungkinan faktor yang mempengaruhi prestasi belajar bahasa Arab mahasiswa Bidikmisi di Ma'had Al-Jami'ah IAIN Kendari adalah faktor minat, kecerdasan, lingkungan, sarana dan lain sebagainya. Hal itu ditunjukkan pleh hasil analisis korelasi dengan menggunakan rumus koefisien determinasi. Hasil analisis menunjukkan bahwa motivasi belajar hanya memberikan sumbangsih sebesar 2,5\% terhadap prestasi belajar. Sedangkan berdasarkan pembahasan hasil penelitian dan hasil uji analisis statistik inferensial dapat disimpulkan bahwa tidak terdapat hubungan antara motivasi belajar dengan prestasi belajar bahasa Arab mahasiswa Bidikmisi di Ma'had Al-Jami'ah IAIN Kendari dimana $\mathrm{r}_{\text {hitung }}=0,16 \leq \mathrm{r}_{\text {tabel }}=0,320$ dan $\mathrm{t}_{\text {hitung }}=1 \leq \mathrm{t}_{\text {tabel }}=1,685$.

\section{PENUTUP}

Berdasarkan uraian pembahasan hasil penelitian di atas, maka dapat disimpulkan beberapa hal. Pertama, deskripsi data variabel $\mathrm{X}$ (motivasi belajar) berada pada interval presentase 61-80\% menunjukan motivasi belajar bahasa Arab mahasiswa Bidikmisi di Ma'had Al-Jami'ah IAIN Kendari pada kategori tinggi dengan data frekuensi 24 dengan presentase (60) \%. Tinggi atau rendahnya motivasi belajar mahasiswa dapat diketahui dari seberapa besar dorongan dan kemauan untuk selalu belajar sehingga tujuan yang dikehendaki dapat tercapai. Motivasi belajar mahasiswa dipengaruhi oleh dua faktor yaitu: faktor intrinsik dan ekstrinsik. Faktor intrinsik meliputi adanya hasrat dan keinginan untuk berhasil, adanya dorongan dan kebutuhan dalam belajar, dan adanya harapan dan cita-cita masa depan. Faktor ekstrinsik meliputi adanya penghargaan dalam belajar, adanya lingkungan belajar yang kondusif serta adanya kegiatan yang menarik dalam belajar. Hal ini sesuai dengan hasil penelitian motivasi belajar bahasa Arab mahasiswa Bidikmisi di Ma'had AlJami'ah IAIN Kendari yang berada pada kategori tinggi.

Deskripsi data variabel Y berada pada interval 61- 80\% menunjukkan prestasi belajar bahasa Arab mahasiswa Bidikmisi di Ma'had Al-Jami'ah IAIN Kendari pada kategori tinggi dengan data frekwensi 20 dengan presentase (50\%). Tinggi atau rendahnya prestasi belajar bahasa Arab mahasiswa Bidikmisi diketahui dari hasil ujian akhir tahun ajaran 2016/2017. Hal ini sesuai dengan hasil penelitian prestasi belajar bahasa Arab mahasiswa Bidikmisi di Ma'had Al-Jami'ah IAIN Kendari pada kategori tinggi.

Dari hasil uji analisis inferensial diperoleh hasil tidak ada hubungan antara motivasi belajar dengan prestasi belajar dimana $\mathrm{r}_{\text {hitung }} \leq \mathrm{r}_{\text {tabel }}\left(\mathrm{r}_{\text {hitung }}=\right.$ $\left.0,16 \leq \mathrm{r}_{\text {tabel }}=0,320\right)$ pada uji t tidak signifikan, karena $\mathrm{t}_{\text {hitung }} \leq \mathrm{t}_{\text {tabel }}$ dimana $\left(\mathrm{t}_{\text {hitung }}=1 \leq \mathrm{t}_{\text {tabel }}=1,685\right)$. Hal ini bermakna bahwa $\mathrm{H}_{1}$ ditolak dan $\mathrm{H}_{0}$ diterima. Artinya, tidak terdapat hubungan antara kedua variabel tersebut. Hal itu 
terbukti pada analisis korelasi dengan menggunakan rumus koefisien determinasi dimana motivasi belajar hanya memberikan sumbangsih sebesar 2,5\% terhadap prestasi belajar dan sisanya 97,5\% dipengaruhi oleh faktor lain yang tidak dibahas dalam penelitian ini seperti faktor minat, kecerdasan, lingkungan, sarana dan lain sebagainya.

\section{DAFTAR PUSTAKA}

Arikunto, S. (2006). Prosedur penelitian suatu pendekatan praktik. Jakarta: Rineka Cipta.

Burhan. (2011). Teknik analisa data statistik pendidikan. Kendari: LPSK Quantum.

Daryanto, D. (2009). Panduan proses pembelajaran kreatif dan inovatif. Jakarta: Publisher.

Departemen Pendidikan Kebudayaan. (1999). Kamus besar bahasa Indonesia. Jakarta: Balai Pustaka.

Djamarah, S. B. (2008). Psikologi belajar. Jakarta: Rineka Cipta.

Dornyei, Z. (Ed.). (2001). Motivational strategies in the language classroom. Cambridge, UK: Cambridge University Press.

Hamalik, O. (1995). Kurikulum dan pembelajaran. Jakarta: Bumi Aksara.

Harahap, N. (1979). Teknik penilaian hasil belajar. Jakarta: Bulan Bintang.

Hermawan, A. (2011). Metodologi pembelajaran bahasa Arab. Bandung: PT Remaja Rosdakarya Offset.

Huitt, W. (2011). Motivation to learn: An overview. Educational Psychology Interactive. Valdosta, GA: Valdosta State University. Retrieved from http://www.edpsycinteractive.org/topics/motivation/motivate.html

Inah, E. N. (2007). Statistik pendidikan. Kendari: Istana Profesional.

Kardon. (2012). Hubungan antara motivasi dan prestasi belajar pendidikan agama Islam. Kendari: LPSK Quantum. 
Kementerian Agama RI. (1989). Al-Quran dan terjemahannya. Semarang: CV. Toha Putra.

La Hadisi. (2009). Strategi pembelajaran. Kendari: CV. Shandra.

Machmud, H. (2006). Media pembelajaran. Kendari: Istana Profesional.

Mulu, B. (2011). Pembelajaran bahasa Arab. Kendari: LPSK Quantum.

Nasution, A. H. (2002). Panduan berpikir penelitian secara ilmiah bagi remaja. Jakarta: PT. Grafindo.

Purwanto, N. M. (2004). Psikologi pendidikan. Bandung: Remaja Rosdakarya.

Riduwan. (2008). Rumus dan data dalam analisis statistik. Bandung: Alfabeta.

Rosyidi, A. W. (2007). Media pembelajaran bahasa Arab. Malang: UIN Malang Press.

Sabri, M. A. (2001). Pengantar psikologi umum dan perkembangan. Jakarta: CV. Pedoman Ilmu Jaya.

Sardiman, A. M. (1988). Interaksi dan motivasi belajar mengajar. Jakarta: Rajawali Pers.

Soehartono, I. (1999). Metode penelitian sosial. Jakarta: Erlangga.

Suaibah. (2012). Pengaruh kompetensi kepribadian dosen terhadap motivasi berprestasi mahasiswa jurusan Tarbiyah STAIN Qaimuddin Kendari. Skripsi tidak dipublikasikan. STAIN Sultan Qaimuddin, Kendari.

Sudijono, A. (2003). Pengantar statistik pendidikan. Jakarta: Raja Grafindo.

Sudjana. (1996). Metode statistik. Bandung: Tarsito.

Sugiyono. (2003). Statistik untuk penelitian. Bandung: CV. Alfabeta.

Sugiyono. (2004). Metode penelitian administrasi. Bandung: Alfabeta. 
Sultan. (2014). Pengaruh keaktifan berorganisasi terhadap prestasi belajar mahasiswa STAIN Kendari. Skripsi tidak dipublikasikan. STAIN Sultan Qaimuddin, Kendari.

Supramono, \& Sugiarto. (1993). Statistika. Yogyakarta: Andi Offset.

Syah, M. (2002). Psikologi pendidikan dengan pendekatan baru. Bandung: Remaja Rosdakarya.

Syah, M. (2009). Psikologi belajar. Depok: Rajawali Pers.

Syaodih, N. (1980). Sikap belajar siswa aktif dan motivasi dari guru. Malang: IKIP. 